\title{
LIMNOLOGICAL SURVEY OF THREE TROPICAL WATER RESERVOIRS IN EASTERN INDIA
}

\author{
Sanjib Kumar DAS ${ }^{1^{*}}$ and Debajyoti CHAKRABARTY2 \\ ${ }^{1}$ Research Scholar (Environmental Science Department), Netaji Subhas Open University, 1, Wood \\ Burn Park, Kolkata-700020, India \\ ${ }^{2}$ Reader and Head, Department of Zoology, Krishnagar Govt. \\ College, Krishnagar-741101, Nadia, India. \\ *Corresponding author: das_sanjibm@yahoo.com
}

Recibido el 15 de septiembre de 2006 , aceptado para su publicación el 11 de enero de 2007

Publicado "on line" en febrero de 2007

\begin{abstract}
Limnological Survey of three Tropical Water Reservoirs in Eastern India. Plankton communities of three water reservoirs of India reflect direct relationship with organic pollution. The assessment of water quality as high or low organically polluted for three water bodies have been achieved with help of algal community, which can be used as indicator of organic pollution. Algal pollution indices according to Palmer (1969) and Watanabe's (1962) based on genus and species were used in rating water samples for high or low organic pollution. Among 26 genera found in India 20 most frequent and common genera of algae were taken into account for indexing pollution status. Water Quality Index (WQI) on the basis of weighting and rating of the chemical parameter was also used to correlate the Palmer index with Physical-chemical parameters of water reservoirs.
\end{abstract}

Key Words. Palmer Index, organic pollution, water reservoir, algae, plankton, water quality index.

RESUMEN. Estudio limnológico de tres embalses de la India Oriental. Las comunidades planctónicas de tres embalses de la India reflejan relaciones directas con la polución orgánica. Se ha evaluado la calidad del agua de estos embalses atendiendo a la comunidad algal que alojan, lo que puede usarse como indicador de polución orgánica. Se ordenaron las muestras de agua, desde alta hasta baja polución orgánica, de acuerdo con los índices de Palmer (1969) y Watanabe (1962) basados en géneros y especies. Entre los 26 géneros encontrados en la India, se seleccionaron los 20 más comunes y frecuentes para los cálculos de los índices citados. También se calculó el índice de la calidad del agua (Water Quality Index, WQI), y se correlacionó con el índice algal de Palmer así como con los parámetros físico-químicos del agua de los embalses.

Palabras clave. Índice de Palmer, polución orgánica, embalses, algas, plancton, índice de calidad del agua.

\section{INTRODUCTION}

Plankton is a kaleidoscopic spectrum of organisms with representatives from almost all phyla of animals and thousands of non flowering plants. From unicellular protozoans, invertebrates, bacteria to diatoms, all drift around as the plankton 
community. The rate of production of plankton is determined by a host of environmental parameters like physicochemical properties of water and soil, meteorological characteristics of the region and morphometric and hydrographic features of the water body (Dahl and Wilson, 2000). It has been found that the relationship between phyto and zooplankters was both inverse and direct during different seasons of the year. A direct relationship exists between plankton production and pollution of water body. Common phytoplankton species belonging to various groups of algae has been listed and grouped under

Cyanophyceae, Chlorophyceae, Bacillariophyceae, Dianophyceae etc. Research in the freshwater ecology of algae related to water pollution is sparse, and it is necessary of detailed study for searching indicator species (Gunale and Balakrishnan, 1981). The present investigation was under taken to study the algae of polluted waters of three water reservoirs of Krishnagar city of district Nadia of West Bengal an eastern state of India. The aim of the present research to find out the presence of indicator phytoplankton species in organically polluted sites.

\section{Study Area}

The morphometric and hydrological characteristics of three chosen reservoirs are located in the city of Krishnagar in West Bengal State of India. The three sites investigated are situated near the tropic of cancer situated at longitude $88^{\circ} 33^{\prime} \mathrm{E}$, latitude $23^{0} 24 \mathrm{~N}$, of eastern province of India. The sampling sites were chosen from Water Reservoir-I, Water Reservoir-II and Water Reservoir-III.

Niche characterization: Water Reservoir I (WR-I)

It is located in the north direction of
Krishnagar city near National Highway 34. It is a permanent Water Reservoir of about 0.33 Hectare. The depth of the WR-I is 1.50 meter. The point source pollution of WR-I was increased due to agricultural run off, regular washing of cloths by washer man, decomposition of jute plants, dumping of industrial waste (Brick Factory) and by addition of wastewater from nearby areas.

\section{Water Reservoir II (WR-II)}

It is located in the north direction of Krishnagar city near National Highway 34. It is a permanent Water Reservoir. The catchment area of the Water Reservoir is of about 0.37 Hectare. The depth of the WR-II is about 1.4 meter. The WR-II gets effluents regularly from cattle washing, from domestic wastewater, the decomposition of jute plants, and the immersion of clay idols the main reason of pollution

\section{Water Reservoir III (WR-III)}

It is located in the east direction of Krishnagar city. It is a permanent Water Reservoir. The area of the Water Reservoir is about 0.23 Hectare. The depth of the WRIII is about 1.1 meter. The Water Reservoir III receives external domestic refuse, agricultural run off soil erosion resulting in loss of biota.

\section{MATERIALS AND METHODS}

Water samples were collected once a month from all the three water reservoirs for Physical-chemical and bacteriological analysis. Subsurface samplings were done through plastic containers (volume approx. 2 lit.) during 9 a.m. to 11 a.m. from depth a depth of $5 \mathrm{~cm}$. Temperature and $\mathrm{p}^{\mathrm{H}}$ were measured immediately after collection of the sample. Physical-chemical analysis for Conductivity, Dissolved Oxygen (D.O.), 
Biological Oxygen Demand (B.O.D.) initial, Total Dissolved Solids (TDS), Total alkalinity, Total Hardness, Ammonia cal nitrogen were performed in the laboratory on same day or within a week. Analyses of all parameters were done following the standard methods as out lined in Standard Methods (2002) and in Wetzel and Likens (2004).

Water Quality Index (WQI) (Fig 1) values were calculated (Ott, 1978; Harkins, 1974) on the basis of weighting and rating of the chemical parameter as follows.

$$
\mathrm{WQI}(\mathrm{Q})=\sum^{\mathrm{i}=\mathrm{n}} \quad \mathrm{w}_{\mathrm{i}} \mathrm{q}_{\mathrm{i}}
$$

Where $\mathrm{w}_{\mathrm{i}}$ and $\mathrm{q}_{\mathrm{i}}$ are the unit weight and the quality rating of the $i^{\text {th }}$ parameter respectively.

WQI for various water bodies were calculated as follows.

The weighting $\left(\mathrm{w}_{\mathrm{i}}\right)$ for various water quality parameters are assumed to be inversely proportional to the recommended standard. The proportionality constant $\mathrm{K}$ is calculated as per following formula.

$$
\begin{aligned}
& \mathrm{K}=1 / \sum^{\mathrm{i}=\mathrm{n}} 1 / \mathrm{v}_{\mathrm{i}}, \\
& \mathrm{q}_{\mathrm{i}}=100 \sum^{\mathrm{i}=1}\left(\mathrm{v}_{\mathrm{i}} / \mathrm{s}_{\mathrm{i}}\right)
\end{aligned}
$$

Where $v_{i}$ is the measured value of the $i^{\text {th }}$ parameter and $s_{i}$ is the standard of permissible value. This equation ensures that $\mathrm{q}_{\mathrm{i}}=0$ when a pollutant is totally absent in water and $\mathrm{q}_{\mathrm{i}}=100$ when the value of this parameter is just equal to its permissible value. Thus the higher the value of $q_{i}$ the more polluted is the water. However, $\mathrm{q}_{\mathrm{pH}}$ and $\mathrm{q}_{\mathrm{D} \text {.o. }}$ were calculated on the basis of

$\mathrm{q}_{\mathrm{pH}}=100 \Sigma\left(\mathrm{v}_{\mathrm{pH}}-7.00\right) /(8.50-7.00)$ considering the ideal value of $\mathrm{pH}$ is 7.00 and

$$
\mathrm{q}_{\text {D.o. }}=100 \Sigma\left(14.60-\mathrm{v}_{\text {D.o }}\right) /(14.60-
$$
$3.00)$ as the ideal value of D.O. is 14.60 mg.! $!^{-1}$ (the solubility of pure $\mathrm{O}_{2}$ in pure water at $0^{0} \mathrm{C}$ ) and $3.00 \mathrm{mg} \cdot \mathrm{1}^{-1}$ is the minimum standard value.

Water Quality Index (WQI) values (Fig 1), a subjective indices, to represent the actual condition of water quality, has been computed considering the level of $\mathrm{pH}$, Conductivity, Dissolved Oxygen (D.O.). WQI values could be classified as < 50=Excellent; $51-80=$ Good; $81-110=$ Fair; $111-140=$ Poor; $\quad>140=$ Unacceptable (IWMED, 2002).

Algal samples were collected at monthly intervals from three water reservoirs of Krishnagar city of district Nadia of West Bengal during January, 2003 to December, 2004. The quantitative and qualitative study of four groups of algae viz., Bacillariophyceae, Cyanophyceae, Chlorophyceae and Euglenophyceae was made for two years. Free and floating phytoplanktonic alga (epiphytic) were collected using a plankton net made up of nybolt cloth (No. 48) and the epilithic alga were sampled from the upper surface of boulders (255 $\mathrm{mm}$ surface area) with a suitable brush developed in the laboratory. Samples were allowed to settle for 24 hour and the supernatant decantated after sieving through plankton net.

The list of pollution tolerant genera and species of algae were recorded. Algal pollution indices according to Palmer (1969) based on genus and species were used in rating water samples for high or low organic pollution. 20 most frequent genera of algae were taken into account. A pollution index factor was assigned to each genus by determining relative number of total points scored by each algae.

The following numerical values for individual zones have been followed Palmer (1969): 


\begin{tabular}{|c|c|c|c|c|c|}
\hline Sr. No. & Genera & Total Points & WR-I & WR-II & WR-III \\
\hline 1 & Oscillatoria & 171 & + & + & + \\
\hline 2 & Euglena & 162 & + & + & + \\
\hline 3 & Chlamydomonas & 114 & + & + & + \\
\hline 4 & Scenedesmus & 113 & + & + & + \\
\hline 5 & Chlorella & 102 & - & + & + \\
\hline 6 & Nitzschia & 99 & + & + & + \\
\hline 7 & Navicula & 91 & + & + & + \\
\hline 8 & Synedra & 59 & + & + & + \\
\hline 9 & Ankistrodesmus & 56 & - & - & + \\
\hline 10 & Phacus & 58 & - & + & + \\
\hline 11 & Phormidium & 51 & + & + & + \\
\hline 12 & Cyclotella & 48 & + & + & + \\
\hline 13 & Closterium & 44 & + & + & - \\
\hline 14 & Pandorina & 43 & + & - & + \\
\hline 15 & Lepocindis & 37 & + & + & + \\
\hline 16 & Spirogyra & 38 & + & - & + \\
\hline 17 & Anabaena & 35 & - & - & + \\
\hline 18 & Pediastrum & 36 & + & - & - \\
\hline 19 & Trachelomonas & 33 & - & + & - \\
\hline 20 & Fragillaria & 35 & - & + & - \\
\hline 21 & Chlorogonium & 32 & + & - & - \\
\hline 22 & Ulothrix & 34 & - & - & + \\
\hline 23 & Eudorina & 29 & + & + & + \\
\hline 24 & Lyngbya & 29 & - & - & + \\
\hline 25 & Spirulina & 24 & + & - & - \\
\hline 26 & Cymbella & 25 & + & + & + \\
\hline 27 & Coelastrum & 23 & + & + & - \\
\hline 28 & Achnanthes & 20 & + & - & - \\
\hline 29 & Pinnularia & 17 & + & + & - \\
\hline 30 & Cosmarium & 18 & + & - & - \\
\hline 31 & Staurastrum & 15 & + & + & - \\
\hline 32 & Selanastrum & 16 & - & + & + \\
\hline
\end{tabular}

Table 1. Pollution tolerant genera of algae from three Water Reservoir in order to decreasing emphasis (Palmer, 1969). Géneros de algas presentes en tres embalses de la India, tolerantes a la polución, ordenados en orden decreciente según el índice de Palmer (1969).

00-10 suggests lack of organic pollution. pollution.

$10-15$ indicates moderate pollution.

15-20 indicates probable high organic pollution.

20 or more confirmed high organic
44-Theoretical maximum (Probably not attainable except under the most stringent artificial conditions).

We also performed the calculation based 


\begin{tabular}{rlcccc}
\hline Sr. No. & \multicolumn{1}{c}{ Species } & Total Points & WR-I & WR-II & WR-III \\
\hline 1 & Oscillatoria limosa & 94 & + & & + \\
2 & Euglena viridis & 41 & + & - & + \\
3 & Scenedesmus quadricauda & 42 & + & + & - \\
4 & Synedra ulna & 32 & + & + & + \\
5 & Oscillatoria chlorina & 30 & - & + & - \\
6 & Chlorella vulgaris & 28 & - & + & + \\
7 & Cyclotella meneghiniana & 28 & + & + & + \\
8 & Euglena gracillis & 25 & - & + & - \\
9 & Navicula cryptocephala & 26 & + & - & - \\
10 & Euglena oxyuris & 20 & + & - & \\
11 & Closterium acerosum & 22 & + & - & - \\
12 & Euglena acus & 19 & - & - & + \\
13 & Synedra acus & 15 & + & + & + \\
14 & Coelastrum microporum & 13 & + & + & + \\
15 & Navicula cuspidata & 13 & + & - & - \\
16 & Pediastrum duplex & 11 & + & - & - \\
17 & Trachelomonas volvocina & 12 & - & + & - \\
18 & Euglena proxima & 9 & - & + & - \\
19 & Tetraedron muticum & 11 & - & + & - \\
\hline
\end{tabular}

Table 2. Pollution tolerant species of algae from three Water Reservoir in order of decreasing emphasis (Palmer, 1969). Especies de algas tolerantes a la polución en tres embalses de la India, ordenados en orden decreciente según el índice de Palmer (1969).

on Watanabe's (1962) index of the relative degree of water pollution based upon types of diatoms to assess organic pollution of the chosen water bodies:

$2 \mathrm{~A}+\mathrm{B}-2 \mathrm{C} / \mathrm{A}+\mathrm{B}-\mathrm{C} \diamond 100$

Where,

$A=$ number of intolerant species
$B=$ number of indifferent species
$C=$ number of pollution tolerant species

\section{RESULTS}

In present investigation a total of 32 pollution tolerant genera of algae were recorded in three water reservoir. The three water reservoirs were evaluated using the values of Palmer index (1969) of pollution (tab.1). Pollution tolerant species of algae from three water reservoirs in order of decreasing emphasis are shown in table 2. In present study 19 pollution tolerant species of algae were observed in water reservoirs (tab.2). The total score for any reservoir was always greater than twenty indicating the high organic pollution (tab.3). In this study common 12 pollution tolerant genera of algae were observed in water reservoirs (tab.1). Out of twelve common genera Oscillatoria was found to be the highest participant in all the water reservoirs. WQI (Water Quality Index) value have been tested and found to vary between 111.54-122.64 in case of WRI, 115.61-128.60 in case of WR-II and 120.46-131.90 in case of WR-III (fig. 1). The mean value for three water reservoirs showed 


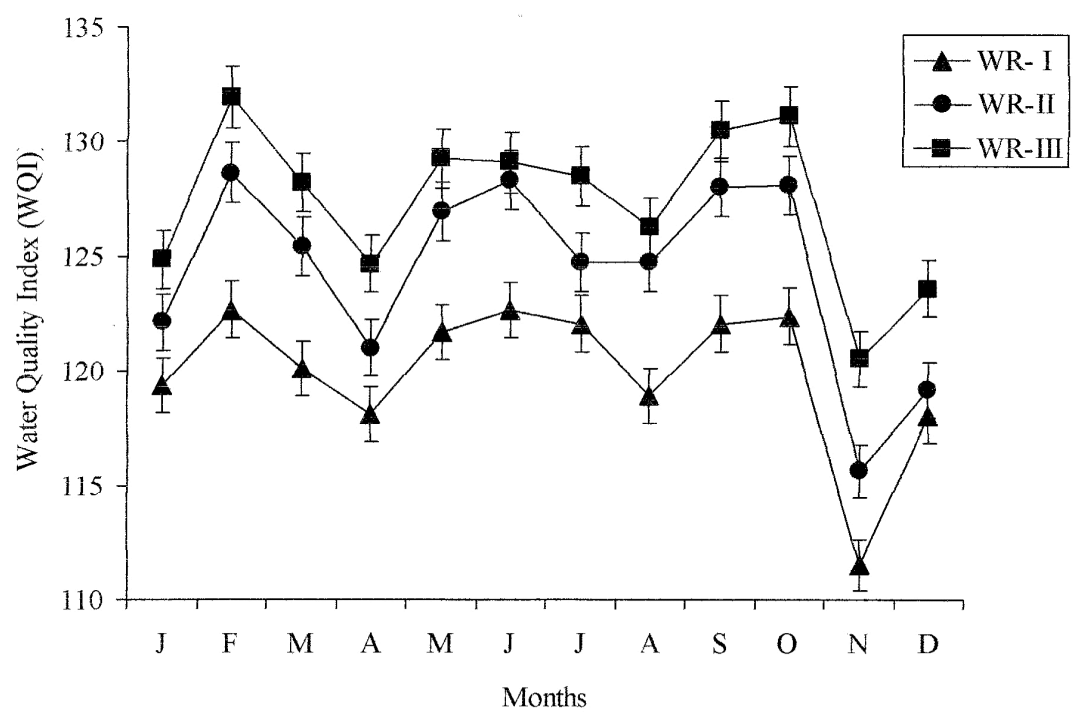

Figure 1. Mean monthly variation of Water Quality Index (WQI) during the study period for the three Water Reservoirs.

a marked ditterence $(\leq \supset \mathrm{U})$. We tound a close resemblance $(\mathrm{r}=0.54 ; \mathrm{P}<0.051)$ between mean WQI (Water Quality Index) value and Palmer's index of pollution. The calculation of Watanabe's index also showed higher values for the three water reservoirs studied and was similar trend (tab.3).

The result of the physico-chemical parameters in water reservoir-III and compared to other two reservoirs shows the dissolved oxygen content in water reservoirIII remained $\leq 2 \mathrm{mg} . ! !^{-1}$ through most of the time of the year (November-January). During the October monsoon season, the organic matter present in the surface runoff reduced the level to $1 \mathrm{mg} . ! 1^{-1}$, (tab.4) which is likely at or near the effect concentration for aquatic life (Jhingran, 1997) .This DO sag indicated the continuous presence of substantial amount of dissolved organic load in the water. This DO sag indicated the continuous presence of substantial amount of dissolved organic load in the water. In contrast, the other two reservoirs (WR-I and WR-II) remained in a better state with respect to dissolved oxygen through most of the time of the year (tab.4). Slight reductions in oxygen concentration were observed during monsoon (Jun-Aug) months. The average level of BOD was high in case of WR-III (tab.4) and the modes of seasonal variation in these aquatic bodies were to some extent similar (tab.4). The mean level of hardness of water reservoir-III was higher than other two reservoirs (WR-I and WR-II) during study period and showed a similar trend in seasonal variation (tab.4). The variation in case of total alkalinity showed similar trend with hardness (tab.4).

Specific conductance remained almost unaltered during the study period and showed higher values $\left(<200 \mu \mathrm{S} . \mathrm{cm}^{-1}\right)$ than normal concentration in all the reservoirs. We found a good correlation between higher values of specific conductance and Cyanophyceae group of algal population $(\mathrm{r}=0.76$; $\mathrm{P}<$ 0.001 ) in the three water reservoirs studied. Temperature was recorded highest during April - May $\left(>40^{\circ} \mathrm{C}\right)$ and showed its lowest value during January - February $\left(>10^{\circ} \mathrm{C}\right)$ 


\begin{tabular}{|c|c|c|c|c|}
\hline \multirow[t]{2}{*}{ Group } & \multirow[t]{2}{*}{ Genera } & \multicolumn{3}{|c|}{ Palmer's Index numbers } \\
\hline & & WR-I & WR-II & WR-III \\
\hline \multirow[t]{5}{*}{ 1. Bacilloriophyceae } & Navicula & 3 & 3 & 3 \\
\hline & Nitzschia & 3 & 3 & 3 \\
\hline & Chlorella & 1 & 1 & 1 \\
\hline & Synedra & 2 & 2 & 2 \\
\hline & Fragillaria & - & - & 1 \\
\hline \multirow[t]{4}{*}{ 2. Cyanophyceae } & Oscillatoria & 5 & 5 & 5 \\
\hline & Phormidium & 1 & 1 & 1 \\
\hline & Spirulina & 1 & 1 & - \\
\hline & Lyngbya & - & - & 1 \\
\hline \multirow[t]{8}{*}{ 3. Chlorophyceae } & Chlamydomonas & 4 & 4 & 4 \\
\hline & Chlorella & - & 3 & 3 \\
\hline & Ankistrodesmus & - & - & 2 \\
\hline & Closterium & 1 & 1 & - \\
\hline & Pandorina & 1 & - & 1 \\
\hline & Eudorina & 1 & 1 & 1 \\
\hline & Scenedesmus & 4 & 4 & 4 \\
\hline & Pediastrum & - & - & - \\
\hline \multirow[t]{4}{*}{ 4. Euglenophyceae } & Euglena & 5 & 5 & 5 \\
\hline & Phacus & - & 2 & 2 \\
\hline & Lepocindis & - & 1 & 1 \\
\hline & Total & 32 & 37 & 40 \\
\hline \multicolumn{2}{|c|}{ Watanabe's (1962) index } & 250 & 257 & 333 \\
\hline
\end{tabular}

Table 3 Palmer's Pollution Index in the three Water Reservoirs. Índice de polución de Palmer (1969) en tres embalses de la India.

(tab.4). We have found a positive correlation with the temperature and occurrence of Chlorophyceae group of alga $(\mathrm{r}=0.80 ; \mathrm{P}<$ $0.001)$ in the three water reservoirs. The $\mathrm{PO}_{4}^{-}$ $P$ values were found to be directly proportional with occurrence to the abundance of algal populations. A good degree of correlation $(\mathrm{r}=0.82 ; \mathrm{P}<0.001)$ was found between $\mathrm{PO}_{4}-\mathrm{P}$ concentration and the number of pollution tolerant algal group $(r=0.82 ; P<0.001)$. Similar such significant correlation was also found for $\mathrm{NH}_{4}-\mathrm{N}$ concentration $(\mathrm{r}=0.76 ; \mathrm{P}<0.001)$ the number of pollution tolerant algal group.

The use of Watanabe's (1962) and Palmer indexes (1969) reveals a greater pollution in reservoir-III compared to other two reservoirs (tab.3). 


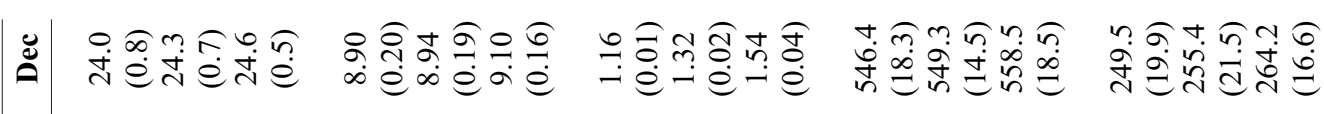

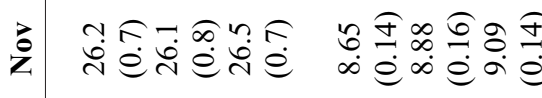

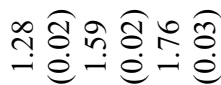

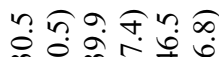

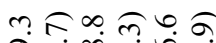

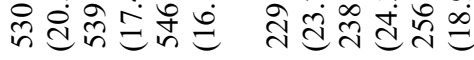

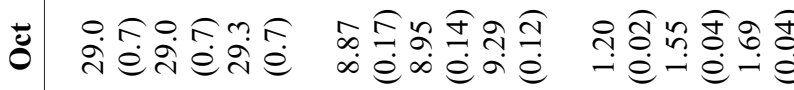

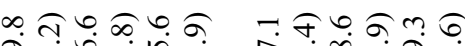
-

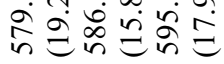

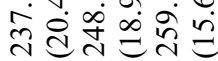
कूँ
ด. 6 เ

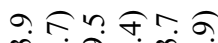

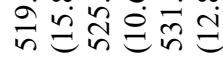

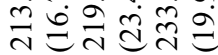

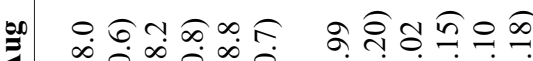

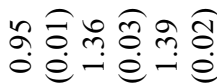
m드으
m $\widehat{\sigma} \infty \cdot \widehat{\infty} \cdot \widehat{\tau}$

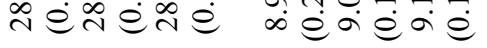

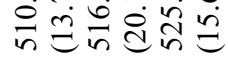
$\overrightarrow{\mathrm{a}} \stackrel{\infty}{=} \stackrel{\text { ป }}{=} \widetilde{\mathrm{n}}$

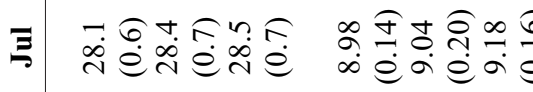

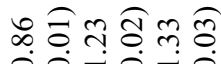

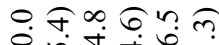
mon

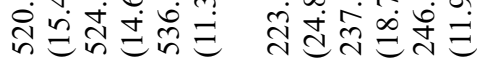

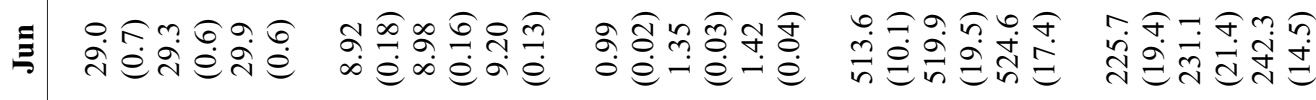

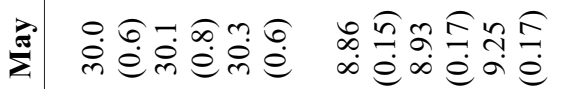

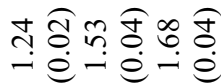

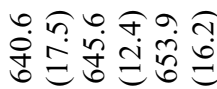
mสิ $\widehat{\sigma} ด$

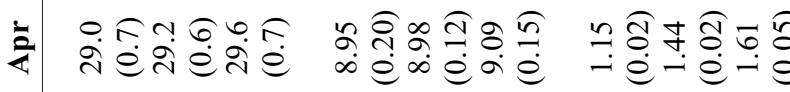

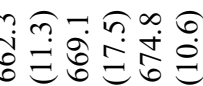
กิ่

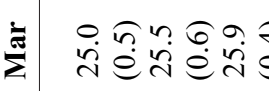

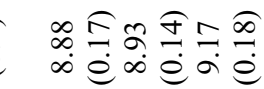

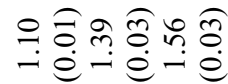

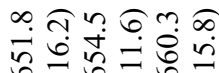
ำ

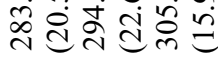

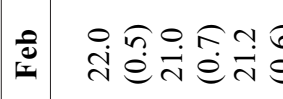

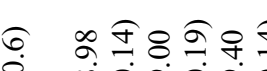
-

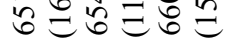

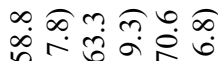
光

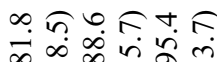
ㅇำ $20 \%$ 市

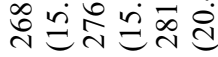
धेंते

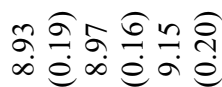

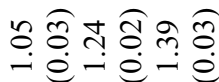
ํำกำ
m 6 ตㄴ.
命气。ํำ
蚉㐫守 


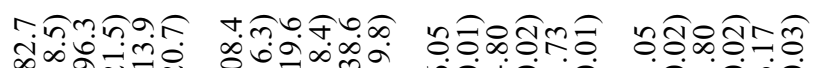

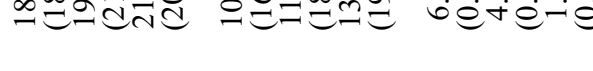

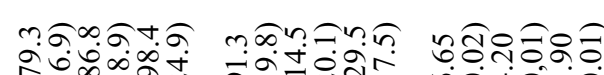

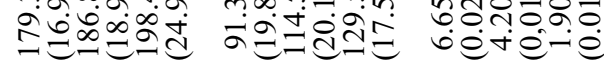

-ie-iene

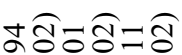

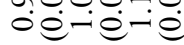

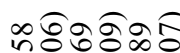

वं 000

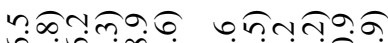

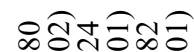

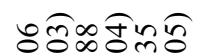

สิ่ณสิริ์

-é-iene

- $\dot{0} \dot{e-i}$

约吉告合

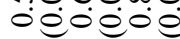

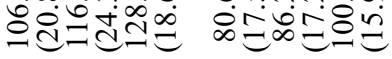

ริึกสิ์

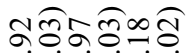

oéteoe re-ienie

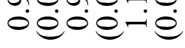

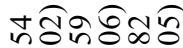

०ण

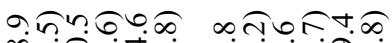

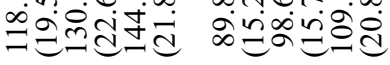

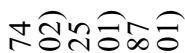

ชูกิศสำ

ทุซิรสิกสิ์

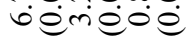

-ie-iene

0ं०ं-ie

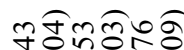
0ं0ं0ं

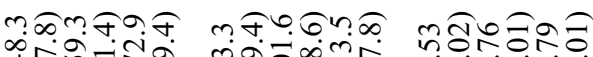

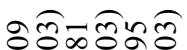

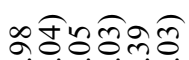

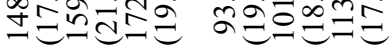

rienié

-ie-iené

oe-iéie

รสิ์ำสิ

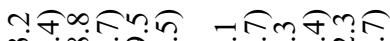

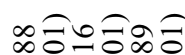

riñ

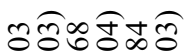

réméं

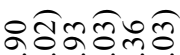

०ण0ं-ie

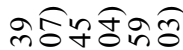
0ं0ं00

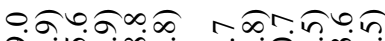

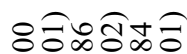

วสิกสิ่สิิ

ทสิรสิกสิ

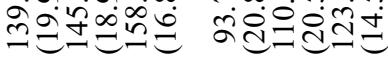

vienieं

-e-ienie

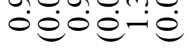

ำกำชิ์

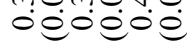

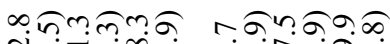

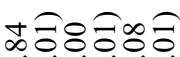

오용ํㅇํㅇ

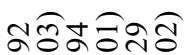

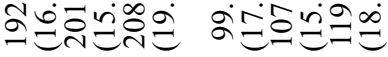

vievie-e

-ieieme

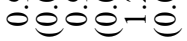

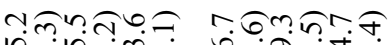

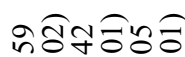

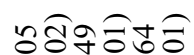

ฉสิกสิกสิ nंeेंe-e

-ie-ienie

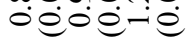

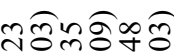

०ण्ण0ं

으응 0ं00ं0

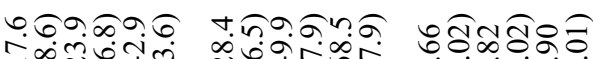

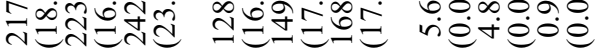

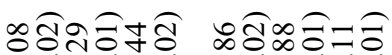
-iéeive

0ं0ं-ie

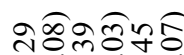
0ं000

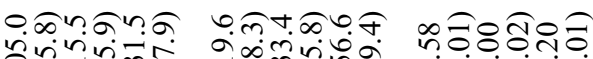

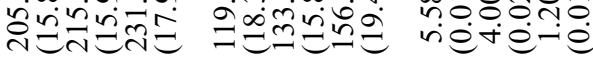

๖สิษสิ์สิ์

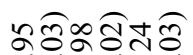
-ie-iené

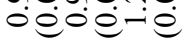

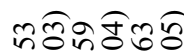
0ं0ं0.

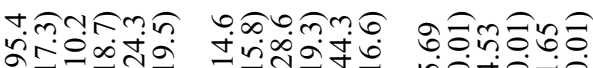

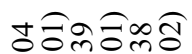

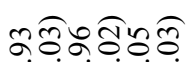

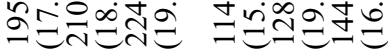
ri்

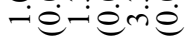

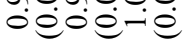

ซริธสิ์สำ ०0ं00

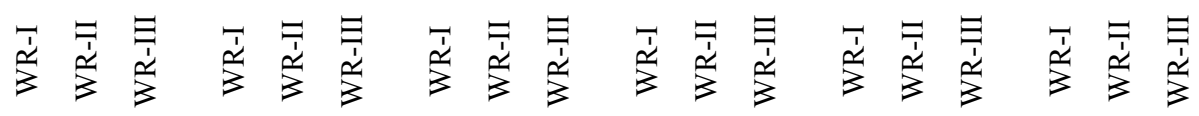
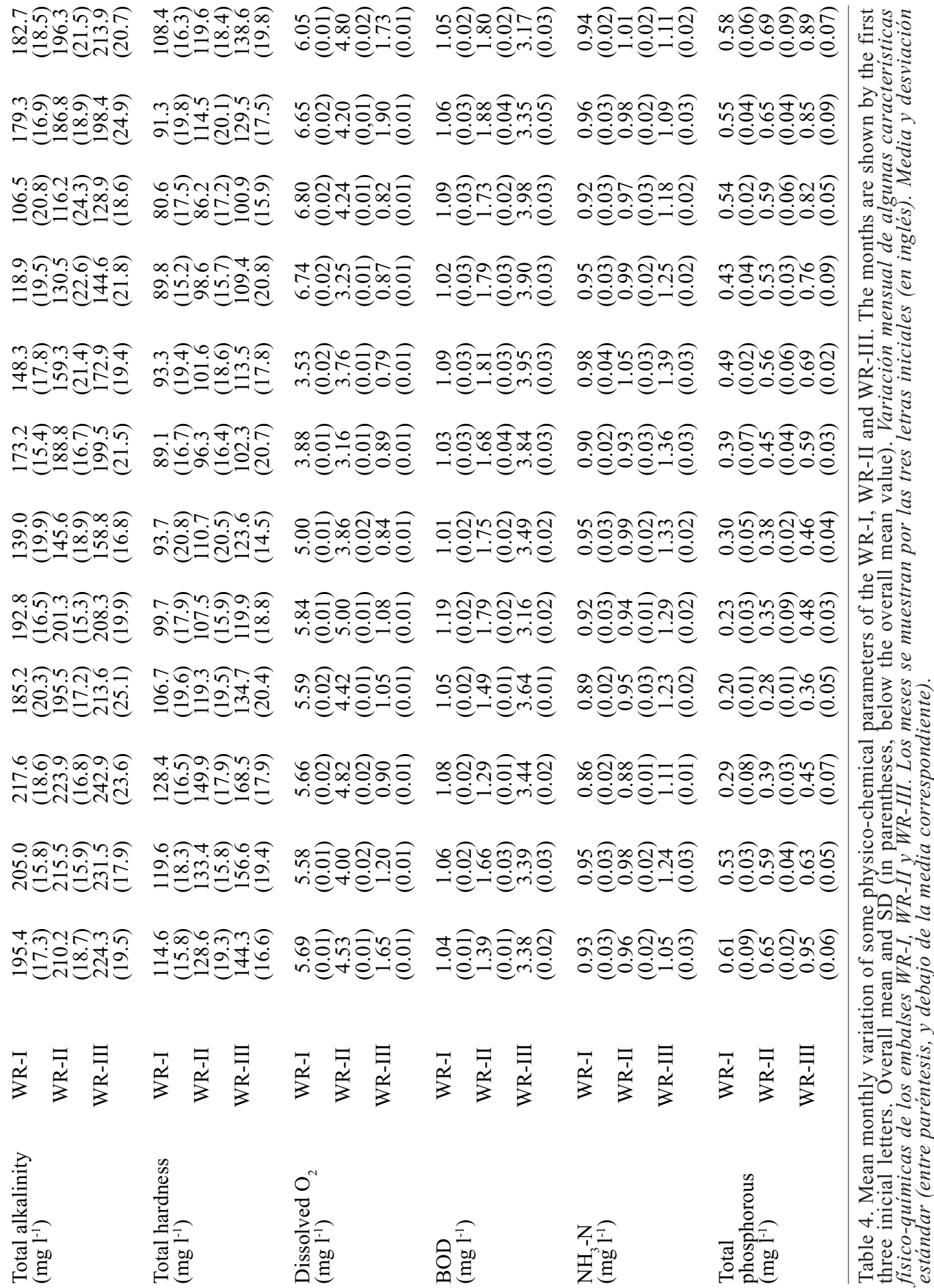


\section{DISCUSSION}

Throughout the globe algal communities are used to study aquatic pollutions and the use of algal communities can be correlated with water pollution studies (Sonneman et al., 2001; Walsh, 2000; Bate et al., 2002). The most important effect of organic pollution in a water bodies is due to enrichment of nutrients and total number of algal species (Winter and Duthie, 2000). Prasad and Singh (1980) emphasized the importance of biological survey in monitoring water quality, which is dependent on qualitative and quantitative composition of aquatic population. Algal communities are generally abundant, diverse and important component in aquatic ecosystem. They collectively show a broad range of tolerance along a gradient of aquatic productivity, individual species have specific water chemical requirements (Werner, 1977; Round, 1991).

The epilithic and epiphytic algae may form excellent indicators of water pollution (Round, 1993). In present investigation, the occurrence of Oscillatoria, Phormidium, Lyngbya and Ulothrix as epilithic algae and certain diatom like Gomphonema as epiphytic were recorded repeatedly and considered as indicators of pollution in view of the results of water quality index (Palmer, 1969; Venkateswarlu, 1979; and Nandan \& Patel, 1985a). We have found the higher score for Watanabe's index and Palmer index (tab.3) in case of water reservoir-III, which indicate accentuated levels of eutrophication. The other values of water quality index (Fig 1) and Palmer index (tab.3) also indicates the confirmation for water reservoir-III.

We found a positive correlation between higher values of specific conductance, $\mathrm{PO}_{4}$, $\mathrm{NH}_{4}-\mathrm{N}$, water quality index with Cyanophyceae group of algae in all the three reservoirs, similar to the finding of Rey et al. (2004). However, Pearsall (1932) was the first to show a marked correlation between organic pollution and blue-green algae along with certain diatoms like Melosira sp. The present study revealed the dominance of Oscillatoria in all the reservoirs indicating pollutants are of biological origin and are similar to the observations of Rai \& Kumar (1976) and Coste, Bosca \& Dauta (1991).

Besides, the other two pollution tolerant species such as Euglena and Navicula were recorded in all the three-water reservoirs and shows agreement with earlier findings of Hosmani and Bharati (1980) who studied certain polluted and unpolluted ponds of Karnataka state in India. Recent reports by Newall and Walsh (2005) also indicated these similarities in their observation and confirmed the importance of such assemblage of algae with organic pollution in water bodies.

Many workers (Hosmani and Bharati, 1980; Nandan and Patel, 1985b) used solely Palmer's index of pollution for rating water samples for high or low organic load and found that the total score of each water reservoir was greater than twenty and confirmed high organic pollution in freshwater bodies. In present study, total 32 pollution tolerant genera were recorded and simply indicated that all three water reservoirs were organically polluted. It has been emphasized by many workers that algal communities as a whole are reliable indicators of pollution rather than single algae (Patrick, 1965; Palmer, 1969; Taylor et al. 2004). Recent approach for assessment of pollution therefore, tends to use algal communities as indices rather than single algal indicator as it was true in present study.

\section{REFERENCES}

BATE, G.C., J.B. ADAMS \& J.S. VAN DER MOLEN -2002-Diatoms as Indicators of 
Water Quality in South African River Systems. WRC Report No. 814/1/02. Water Research Commission. Pretoria. 164 pp.

COSTE M., C. BOSCA \& A. DAUTA -1991-. Use of algae for monitoring rivers in France. In: Whiton B A, Rott E and Friedrich G (eds.) Use of Algae for monitoring Rivers. E. Rott, Institüt für Botanik. Univ. Innsbruk. 75-88.

DAHL, M. \& D. WILSON -2000- Current status of freshwater quality models. Technical report, Karlstad University, May 2000.

GUNALE, V.R. \& M.S. BALAKRISHNAN 1981- Biomonitoring of eutrophication in the Pavana, Mula and Mutha rivers through Poona. Indian J. of Environ. Hlth., 23(4), 316322.

HARKINS, R.D. -1974- An objective Water Quality Index. J. Wat. Pollut. Control. Fed. 46, 588.

HOSMANI, S.P. \& S.G. BHARATI -1980- Algae as indicators of organic pollution. Phycos 19(1), 23-26.

IWMED (Institute of Wetland Management and Ecological Design) -2002- Final report on water quality monitoring of Churni River at Ranaghat and Jalangi River at Krishnagar. April-2002, West Bengal Pollution Control Board, Salt Lake City, Kolkata-700098, India.

JHINGRAN, V.G. -1997- Fish and Fisheries of India. Second ed. Hindustan Publishing Corporation, New Delhi, India.

NANDAN, S.N. \& R.J. PATEL -1985aEutrophication in Vishwamitri river flowing through Baroda city. Geobios 2, 60-62.

NANDAN, S.N. \& R.J. PATEL -1985b- Pollution studies of Vishwamitri river flowing through Baroda. Biovigyana 11(2), 209-210.

NEWALL, P. \& C.J. WALSH -2005- Responses of epithilic diatom assemblages to urbanization influences. Hydrobiologia 532, 53-67.

OTT, W.R. -1978- Environmental Indices Theory and Practices, Ann. Arbor. Aci. Publis, Inc: 202-213.

PALMER, C.M. -1969- A composite rating of algae tolerating organic pollution. J. Phycol. 5, 76-82.

PATRICK, R. -1965-Algae as indicator of pollution: An biological problem in water pollution $3^{\text {rd }}$ seminar Robt. A. Tuff Sanitory
Eng. Centre Cincinati Ohio, 223-232.

PEARSALL, W.H. -1932- Phytoplankton in ten English lakes II. J. Ecol. 22, 241-262.

PRASAD, B.N. \& Y. SINGH -1980- Algal hydrobiology in India: A review. Nat. Aca. Sci. Indi., Golden Jubilee Commemoration Vol. 271-300.

RAI, L.C. \& H.D. KUMAR -1976- Systematic and ecological studies on algae of some habitats near Sahupuri, Varanasi. Nova Hedwigia 27, 803-812.

REY PA DE LA, J.C. TAYLOR, A. LAAS, L. VAN RENSBURG \& A. VOSLOO -2004Determining the possible application value of diatoms as indicators of general water quality: A comparison with SASS 5. Water SA Vol. 30 No. 3:325-332.

STANDARD METHODS -2002- Standard Methods for the Examination of Water and Waste Waters (21 ${ }^{\text {st }}$ edn.), American Water Works Association (AWWA), Water Pollution Control Federation (WPCF) and American Public Health Association (APHA) Washington DC, USA.

ROUND, F.E. -1991- Diatoms in river watermonitoring studies. J. Appl. Phycol. 3, 129145.

ROUND, F.E. -1993-A review and methods for the use of Epilithic Diatoms for Detecting and Monitoring Changes in River Water Quality. Methods for the examination of water and associated materials. HMSO Publications. London.

SONNEMAN, J.A., C.J., P.F. WALSH BREEN \& A.K. SHARPE -2001- "Effects of urbanization on streams of the Melbourne region, Victoria, Australia. II. Benthic diatom communities." Freshwater Biology 46(4), 553-565.

TAYLOR, S.L., S.C. ROBERTS, C.J. WALSH $\&$ B.E. HATT -2004- Catchment urbanisation and increased benthic algal biomass in streams: linking mechanisms to management. Freshwater Biology 49, 835-851.

VENKATESWARLU V. -1979- Taxonomy and ecology of algae in the River Moosi, Hyderabad (India)' Nova Hedwigia 27, 661676.

WALSH, C.J. -2000- "Urban impacts on the ecology of receiving waters: a framework for assessment, conservation and restoration." 
Hydrobiologia 431(2), 107-114.

WATANABE, T. -1962- On the biotic index of water pollution based upon the species number of Bacillariophyceae in the Tokoro River in Hokkaido // Jap. Journal of Ecology 12(6), 216-222.

WERNER, D. (ed.) -1977- The biology of Diatoms. University of California Press.
Berkeley. CA.

WETZEL, R.G. \& G.E. LIKENS-20 04Limnological Analysis. ( $3^{\text {rd }}$ edn.) Springer (India) Private Limited, New Delhi, India.

WINTER, J.G. \& H.C. DUTHIE -2000- "Epilithic diatoms as indicators of stream total $\mathrm{N}$ and total P concentration." Journal of the North American Benthological Society 19(1), 32-49. 